\title{
Effect of Sources and Rates of Nitrogen Fertilizers on Forage Yield and Nitrate Accumulation for Sudangrass
}

\author{
S.T. Abo-Zeid ${ }^{1}$, Amal L. Abd EL-Latif ${ }^{1}$ and S. Elshafey ${ }^{2}$ \\ ${ }^{1}$ Dept. Soil Science, Fac. of Agric., Cairo University and ${ }^{2}$ Regional Center of Food \\ and Feed, ARC, Ministry of Agric., Giza, Egypt
}

\begin{abstract}
$\mathbf{A}$ FIELD experiment was carried out at the Experimental Station Farm in Giza, Agricultural Research Center, Egypt, during the two successive summer seasons of 2012 and 2013. The experiment was to study the effect of varying sources, rates of nitrogen fertilizers on fresh and dry forage yields of sudangrass, chemical constituents, nitrate and nitrite accumulation in plant using a split-plot design with three replicates. The main plots were assigned to nitrogen fertilizer sources (Ammonium nitrate NH4 NO3 and ammonium sulphate (NH4)2 SO4.While, the sub-plots were occupied with rates of nitrogen fertilizer $(50,75,100$, and $125 \mathrm{Kg} \mathrm{N} / \mathrm{fed}$ ). The results indicated that the fresh and dry forage yield ton/fed, nitrogen, crude protein, phosphorus, potassium, nitrite (NO2) and nitrate (NO3)contents were significantly decreased in the second cutting as compared with the first one over both seasons. Using ammonium sulphate " $\left(\mathrm{NH}_{4}\right)_{2} \mathrm{SO}_{4}$ " was better than using ammonium nitrate "NH4 NO3" as a source of nitrogen fertilizer over both cuttings and seasons.

Fresh and dry forage yields of sudangrass were significantly increased as nitrogen rates increased from 50 to 75 and $100 \mathrm{~kg} \mathrm{~N} / \mathrm{fed}$ and significantly decreased due to increasing nitrogen rate from 100 to $125 \mathrm{~kg} \mathrm{~N} /$ fed over both seasons.It can be recommended that mineral fertilizing of sudangrass plants with $75100-\mathrm{kg}$ $\mathrm{N} /$ fed is better to get suitable forage yields and reduce nitrate accumulation in plant.
\end{abstract}

Keywords: Sudangrass, Nitrogen fertilizer sources, Nitrate accumulation.

\section{Introduction}

Animal production is suffering scarcity, because of the competition between the production of human food and animal feed in Egypt. Thus, forage become important in mans food supply through its utilization as food by ruminant. In the main time some forage grasses such as sorghum, sudangrass, millet and teosint are the most satisfactory summer fodder crops grown in Egypt to offset the acute deficit in forage production during the summer. Since, the total cultivated area of sudangrass in Egypt reached about 8340 fed in 2011 season, producing 190913 ton, thus the average production was 22.90 ton/fed (ElNahrawy, 2011).

Nitrogen plays a role in plant nutrition. It is the element that required in the greatest quantity by forage crop plants such as sudangrass and it is the nutrient most often deficit in the Egyptian soils. Thus, the adequate rates, appropriate sources, efficient methods of application and application timing are important strategies (Fageria and Baligar, 2005) in order to increase growth, yield and its components and enhances the protein content of sudangrass crop.

Afzal et al. (2012) showed that increasing nitrogen dose from 0 to 50,75 and $100 \mathrm{~kg} \mathrm{~N} /$ acre increased plant height, fresh and dry weight of sorghum forage. Anfinruda et al. (2013) found that there was a significant response in yield with increasing nitrogen rates. They added that there was a significant response in quality parameters such as $\mathrm{N} \%, \mathrm{P} \%, \mathrm{~K} \%$ and crude protein yield with increasing nitrogen rates.

Ammonium nitrate (NH4NO3) is highly soluble in water and readily available to plants. However, it can be lost through leaching and runoff, polluting groundwater and streams. Ammonium sulphate is used as a synthetic stimulant for alkaline soils. The sulphur in the compound helps to decrease the $\mathrm{pH}$ balance of 
the soil while increasing the nitrogen content Ammonium nitrate can also be used as a good plant fertilizer; however it is far better suited to controlling acidic soil. Significant differences in growth characters, yield and its components of sorghum forage were detected owing to nitrogen fertilizers sources (Ahmed et al.. 2007). Mahmoud et al.(2011) showed that there were significant effects on yield and yield components due to nitrogen sources and rates. Using of nitrogen fertilizers at form of ammonium sulphate and urea at the suitable concentrations according to soil type and plant gave higher yield than ammoniun nitrate.

Nitrate accumulation in plants is affected by some factors; excessive use of nitrogen fertilize ferors (drougt, sulight, $\mathrm{Mg}$, ,environmenta

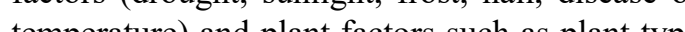
(sorghum, sudangrass, hybrid sorghum and peap (sillet), stage of growth immature or young pear and salks are highest in nitrete or young plants in order by leaves and gan in decearng amount(Roozeboom, 2011).

The objective of this study was to evaluate the impact of different nitrogen fertilizer sources and rates on forage yield of sudangrass and its chemical constituents.

\section{Materials and Methods}

The field experiment was carried out at the Experimental Station Farm in Giza, Agricultura Research Center, Egypt, during the two successive summer seasons of 2012 and 2013 to study the effect of varying sources, rates of nitrogen fertilizer on forage yield of sudangrass and its chemical constituents.

The experiment was carried out in a splitplot design with three replicates. The main plot were assigned to the following nitrogen fertilize

1- Ammonium nitrate "NH4 NO3" $33.5 \% \mathrm{~N}$.

2- Ammonium sulphate "(NH4)2 SO4" $20.6 \% \mathrm{~N}$.

While, the sub-plots were occupied with the following rates of nitrogen fertilizer $(50,75,100$, and $125 \mathrm{Kg} \mathrm{N} / \mathrm{fed}$ ).

The nitrogen fertilizers in the previously mentioned sources and rates were added in three equal portions, one third at sowng, second thir after 20 days from sowing and the other third Egypt. J. Soil Sci. 57 No.1, (2017) after the first cut.Each experimental basic uni included five ridges, each of $70 \mathrm{~cm}$ width and $3 \mathrm{~m}$ length, resulted an area of $10.5 \mathrm{~m} 2(1 / 400$ fed). The preceding winter crop was Egyptia clover (Trifolium alexandrinum L.) in the first and second seasons.

Surface soil samples were taken at random from the experimental field area before cultivatio forsical and chemical soll properties as shown in Table

Particle size distribution was carried out by pipette method as described by Gee an Bauder (1986). Saturation percentage (SP) was 1986). Organic matter was determined by we oxidation method (Sparks, 1996). Total CaCO3 was determined using Collin's calciminer (Sparks, 1996). Available forms of N,P and $\mathrm{K}$ were determined in the soil (Sparks,1996).

Soil $\mathrm{pH}$ and EC were measured in a $1: 2.5$ soil water suspension using combined electrod pH meter and conductivity meter, respectively. Soluble cations, $\mathrm{Na}$ and $\mathrm{K}$ were measured by flam photometer while $\mathrm{Ca}, \mathrm{Mg}$ and soluble anion C., SO4, $\mathrm{CO} 3$ and $\mathrm{HCO}$ ) were deternined Nitrate was determined using described by A. O.A.C (2012). A.C (2012)

Superphosphate (15.5\% P2O5) was applied during soil preparation at the rate of $200 \mathrm{~kg} / \mathrm{fed}$. Potassium sulphate $(48 \% \mathrm{~K} 2 \mathrm{O})$ at the rate of $100 \mathrm{~kg} /$ fed was applied with the second dose of nitrogen fertilizer.

Sudangrass seeds were hand sown in pits in he two sides of the ridge and the distance betwee every two pits was about $20 \mathrm{~cm}$ using dry sowing mert (Afire) during the last week of April in every 12 days throughout the was conducted The of The other agricultural practices were kept the same as nom to recom Agriculture and Land Reclamation.

The first cutting was done after 60 days from sowing. The second cutting was done after 40 days from the first cutting, where one meter square from each sub-plot was randomly chosen to estimate fresh forage yield. Dry forage yield was calculated after washing and oven drying of fresh samples at $70^{\circ} \mathrm{C}$ until constant weight.

TABLE 1. Some Physical and chemical analysis of the experimental soil

\begin{tabular}{|c|c|c|}
\hline \multicolumn{2}{|c|}{ Soil analyses } & Value \\
\hline \multicolumn{3}{|c|}{ Physical analyses } \\
\hline \multicolumn{2}{|c|}{ Clay $(g / k g)$} & 455 \\
\hline \multicolumn{2}{|c|}{ Silt $(\mathrm{g} / \mathrm{kg})$} & 393 \\
\hline \multirow{2}{*}{\multicolumn{2}{|c|}{\begin{tabular}{l|l} 
Fine sand $(g / \mathrm{kg})$ \\
Coarse sand $(\mathrm{g} / \mathrm{kg})$
\end{tabular}}} & 110 \\
\hline & & 42 \\
\hline \multicolumn{2}{|c|}{ Texture class } & Silty loam \\
\hline \multicolumn{2}{|c|}{ SP \% } & 42.0 \\
\hline \multicolumn{3}{|c|}{ Chemical analyses } \\
\hline \multicolumn{2}{|c|}{ Organic matter $(\mathrm{g} / \mathrm{kg})$} & 18 \\
\hline \multicolumn{2}{|c|}{$\mathrm{CaCO}_{3}(\mathrm{~g} / \mathrm{kg})$} & 5 \\
\hline \multirow{2}{*}{\multicolumn{2}{|c|}{$\frac{\mathrm{N}(\mathrm{mg} / \mathrm{kg})}{\mathrm{P}(\mathrm{mg} / \mathrm{kg})}$}} & 50.1 \\
\hline & & 7.0 \\
\hline \multicolumn{2}{|c|}{$\mathrm{K}(\mathrm{mg} / \mathrm{kg})$} & 314.6 \\
\hline \multicolumn{2}{|c|}{$\mathrm{NO}_{3}(\mathrm{mg} / \mathrm{kg})$} & 25.0 \\
\hline \multicolumn{2}{|c|}{$\mathrm{EC}(\mathrm{ds} / \mathrm{m})$ at $25^{\circ} \mathrm{C}$} & 1.1 \\
\hline \multicolumn{2}{|c|}{$\mathrm{pH}$} & 8.1 \\
\hline \multirow{4}{*}{ Cations (meq/L) } & $\mathrm{K}^{+}$ & 2.3 \\
\hline & $\mathrm{Na}^{+}$ & 4.0 \\
\hline & $\mathrm{Mg}^{++}$ & 1.7 \\
\hline & $\mathrm{Ca}^{++}$ & 2.0 \\
\hline \multirow{4}{*}{ Anions (meq/L) } & $\mathrm{SO}_{4}{ }^{2}$ & 1.6 \\
\hline & $\mathrm{Cl}^{-}$ & 6.1 \\
\hline & $\mathrm{HCO}_{3}$ & 2.3 \\
\hline & $\mathrm{CO}_{3}=$ & - \\
\hline
\end{tabular}

The wet digestion of dry matter was carried out using mixed concentrated acids (perchloric and sulphoric acids) according to Page et al.(1982).

Nitrogen content was determined by microjeldahl apparatus, according to O'Dell (1993). Phosphorus was estimated colorimetrically by using the molybdenum blue method accordin to Pierzynski (2000). Potassium was estimated famephotometrically according to Page et (1982) Crude protein content (CP \%) was calculated according to its total $\mathrm{N}$ content, using he 6.25 factor. Nitrate $(\mathrm{NO} 3)$ and nitrite $(\mathrm{NO} 2)$ eterminations were measured as described by A.O.A.C. (2012)

Statistical analysis

All obtained data were statistically analyzed (ANOVA) for the split - plot design as published by Gomez and Gomez (1984).

\section{Results and Discussion}

- Fresh and dry forage yields (ton/fed) Means of fresh and dry forage yields (ton/ fed) as affected by different nitrogen fertilize sources and rates produced from the first and the second cuttings as combined over both season are presented in Table (2). The data indicated the forage yields were significantly decreased in the second cutting as compared with first cutting over both seasons.

In the first cutting, the use of ammonium nitrate was significantly exceeded using ammonium sutphate as sources of nitrogen fertilizer ove seasons. On the contrary, using ammonium Thate was significantly higher than using second cutting ove (2007) results were obtained by differences in yield who showed that significan 作 sources.

Over both seasons, fertilizing sudangras plants with $50 \mathrm{~kg} \mathrm{~N} /$ /ed as ammonium sulphate ammonium nitrate tended to produce the lowes values of fresh and dry forage yields in the firs and second cutting.

Eoypt. J. Soil Sci. $\mathbf{5 7}$ No. 1, (2017) 
TABLE 2. Fresh and dry forage yields (ton/fed) as affected by sources and rates of nitrogen fertilizer produced from first and second cuttings as combined over both seasons.

\begin{tabular}{|c|c|c|c|c|c|c|c|c|}
\hline \multirow[t]{2}{*}{ Cuttings } & \multicolumn{8}{|c|}{ Fresh forage yield (ton/fed) } \\
\hline & \multicolumn{2}{|c|}{$50 \mathrm{~kg} \mathrm{~N} / \mathrm{fed}$} & \multicolumn{2}{|c|}{$75 \mathrm{~kg} \mathrm{~N} / \mathrm{fed}$} & \multicolumn{2}{|c|}{$100 \mathrm{~kg} \mathrm{~N} / \mathrm{fed}$} & \multicolumn{2}{|c|}{$125 \mathrm{~kg} \mathrm{~N} / \mathrm{fed}$} \\
\hline \multicolumn{9}{|c|}{ Ammonium nitrate " $\mathrm{NH}_{4} \mathrm{NO}_{3}$ " } \\
\hline First cutting & 25.10 & \pm 0.31 & 27.15 & \pm 0.30 & 29.07 & \pm 0.40 & 28.10 & \pm 0.38 \\
\hline Second cutting & 18.05 & \pm 0.36 & 20.05 & \pm 0.56 & 21.15 & \pm 0.31 & 20.18 & \pm 0.30 \\
\hline \multicolumn{9}{|c|}{ Ammonium sulphate " $\left(\mathrm{NH}_{4}\right)_{2} \mathrm{SO}_{4}$ " } \\
\hline First cutting & 24.90 & \pm 0.30 & 26.83 & \pm 0.65 & 28.65 & \pm 0.23 & 27.67 & \pm 0.23 \\
\hline Second cutting & 18.75 & \pm 0.51 & 20.90 & \pm 0.28 & 21.85 & \pm 0.28 & 20.90 & \pm 0.23 \\
\hline LSD at $5 \%$ & & 0.71 & & & & 0.58 & & 0.54 \\
\hline \multicolumn{9}{|c|}{ Dry forage yield (ton/fed) } \\
\hline \multicolumn{9}{|c|}{ Ammonium nitrate " $\mathrm{NH}_{4} \mathrm{NO}_{3}$ " } \\
\hline First cutting & 3.82 & \pm 0.08 & 4.26 & \pm .12 & 4.87 & \pm .11 & 4.51 & \pm 0.10 \\
\hline Second cutting & 2.65 & \pm 0.08 & 3.25 & \pm .26 & 3.36 & \pm .08 & 3.14 & \pm 0.08 \\
\hline \multicolumn{9}{|c|}{ Ammonium sulphate " $\left(\mathrm{NH}_{4}\right)_{2} \mathrm{SO}_{4}$ " } \\
\hline First cutting & 3.64 & \pm 0.05 & 4.08 & $\pm \quad .11$ & 4.50 & \pm .06 & 4.19 & \pm 0.08 \\
\hline Second cutting & 2.81 & \pm 0.11 & 3.24 & \pm .05 & 3.63 & \pm .08 & 3.36 & \pm 0.08 \\
\hline LSD at $5 \%$ & & 0.16 & & 0.30 & & 0.16 & & 0.55 \\
\hline
\end{tabular}

-The superscript letters indicated statistically significant differences, with $\mathrm{P}<0.05$.

Fresh and dry forage yields of sudangrass were significantly increased as nitrogen rates increase from 50 to 75 and $100 \mathrm{~kg} \mathrm{N/fed} \mathrm{and} \mathrm{significantly}$ decreased due to increasing nitrogen rate from 100 to $125 \mathrm{~kg} \mathrm{~N} /$ fed over both seasons. The increase in fresh forage yield/fed as a result of increasing nitrogen fertilizer rates up to $100 \mathrm{~kg} \mathrm{~N} /$ fed may be attributed to the role of nitrogen in enhancement meristematic activity and cell division, increasin the vegetative growth through enhancing leaf initiation, increment chlorophyll concentration in leaves and photosynthesis process (Lawlor, 2002) consequently enhancement forage yield/fed. These results are in agreement with those reported by Cupina et al. (2011) and Anfinruda et al. (2013).

2-Nitrogen $(\mathrm{N} \%)$ and crude protein $(\mathrm{CP} \%)$ contents. Means of nitrogen and crude protein content as affected by nitrogen fertilizer sources and rate produced from the first and the second cuttings as combined Table (3)

From obtained results, it could be observe that $\mathrm{N}$ and $\mathrm{CP}$ contents were markedly decreased in the second cutting as compared with nitrogen percent in sudangrass plants in the first cuttin over both seasons. Nitrogen percent in sudangras plants was higher when using ammonium sulphate than using ammonium nitrate in both cuttings and seasons.

Egypt. J. Soil Sci. 57 No.1, (2017)
Nitrogen percent and $\mathrm{CP} \%$ in sudangrass plants were significantly increased as nitrogen fertiliz rates increased from 50 to 75,100 and $125 \mathrm{~kg} \mathrm{~N}$ ed in the first and the second cuttings, respectively over both seasons. The steady increases in nitrogen percent (N\%) in sudangrass plants as a result of increasing nitrogen fertilizer rates up to $125 \mathrm{~kg}$ $\mathrm{N} /$ fed may be attributed to the role of nitrogen in improving growth and dry matter accumulation as well as by the influence of nitrogen availability at critical stages on plant metabolism in a manne which leading to increase synthesis of amino acids (Lawlor, 2002), and consequently enhancement nitrogen percent in forage yield of sudangrass. Beyaert and Roy (2005), Rahman et al. (2008) and Anfinruda et al. (2013) came to similar results.

- The superscript letters indicated statistically significant differences, with $\mathrm{P}<0.05$.

3-Phosphorus and potassium percent

Averages of phosphorus and potassium percent in sudangrass plants as affected by various nitrogen fertilizer sources and rates resulted from the first and the second cuttings as combined over both growing seasons are shown in Table (4).

The data show that phosphorus (P \%) and potassium $(\mathrm{K} \%)$ in sudangrass plants produced from the first cuntung were significantly highe than those resulted from the second on
TABLE 3. Nitrogen and crude protein contents as affected by sources and rates of nitrogen fertilizers produced from first and second cuttings as combined over both seasons.

\begin{tabular}{|c|c|c|c|c|c|c|c|c|c|c|c|c|}
\hline \multirow{2}{*}{ Cuttings } & \multicolumn{12}{|c|}{ Nitrogen content (\%) } \\
\hline & \multicolumn{3}{|c|}{$50 \mathrm{~kg} \mathrm{~N} / \mathrm{fed}$} & \multicolumn{3}{|c|}{$75 \mathrm{~kg} \mathrm{~N} /$ fed } & \multicolumn{3}{|c|}{$100 \mathrm{~kg} \mathrm{~N} / \mathrm{fed}$} & \multicolumn{3}{|c|}{$125 \mathrm{~kg} \mathrm{~N} / \mathrm{fed}$} \\
\hline \multicolumn{13}{|c|}{ Ammonium nitrate $" \mathrm{NH}_{4} \mathrm{NO}_{3} "$} \\
\hline First cutting & 1.43 & \pm & 0.06 & 1.57 & \pm & 0.06 & 1.80 & \pm & 0.03 & 2.00 & \pm & 0.06 \\
\hline Second cutting & 1.40 & \pm & 0.00 & 1.53 & \pm & 0.06 & 1.70 & \pm & 0.04 & 1.80 & \pm & 0.03 \\
\hline \multicolumn{13}{|c|}{ Ammonium sulphate " $\left(\mathrm{NH}_{4}\right)_{2} \mathrm{SO}_{4}$ " } \\
\hline First cutting & 1.53 & \pm & 0.06 & 1.63 & \pm & 0.06 & 1.90 & \pm & 0.57 & 2.10 & \pm & 0.03 \\
\hline Second cutting & 1.47 & \pm & 0.06 & 1.60 & \pm & 0.00 & 1.80 & \pm & 0.05 & 2.00 & \pm & 0.02 \\
\hline LSD at 5\% & & 0.09 & & & 0.09 & & & .09 & & & 0.09 & \\
\hline \multicolumn{13}{|c|}{ Crude protein content (CP\%) } \\
\hline \multicolumn{13}{|c|}{ Ammonium nitrate " $\mathrm{NH}_{4} \mathrm{NO}_{3}$ " } \\
\hline First cutting & $8.97^{\mathrm{ab}}$ & \pm & 0.21 & $9.70^{0 \mathrm{bb}}$ & \pm & 0.100 & $10.8^{\mathrm{a}}$ & \pm & 0.20 & $12.2^{\mathrm{ab}}$ & \pm & 0.10 \\
\hline Second cutting & $8.73^{\mathrm{b}}$ & \pm & 0.15 & $9.50^{0 \mathrm{bb}}$ & \pm & 0.436 & $10.6^{\mathrm{a}}$ & \pm & 0.26 & $11.3^{\mathrm{b}}$ & \pm & 0.61 \\
\hline \multicolumn{13}{|c|}{ Ammonium sulphate “(NH4) $)_{2} \mathrm{SO}_{4} "$} \\
\hline First cutting & $9.60^{2}$ & \pm & 0.36 & $10.47^{\mathrm{a}}$ & \pm & 0.153 & $11.9^{\mathrm{a}}$ & \pm & 0.79 & $12.90^{\mathrm{a}}$ & \pm & 0.36 \\
\hline Second cutting & $9.17^{\mathrm{ath}}$ & \pm & 0.21 & $9.97^{\mathrm{b}}$ & \pm & 0.252 & $11.5^{\mathrm{a}}$ & \pm & 0.53 & $12.0^{00^{\mathrm{ab}}}$ & \pm & 0.25 \\
\hline LSD at $5 \%$ & & 0.46 & & & 0.50 & & & .95 & & & 0.71 & \\
\hline
\end{tabular}

Each value in the table was obtained by calculating the average of the three rep
The superscript letters indicated statistically significant differences, with $\mathrm{P}<0.05$.

TABLE 4. Phosphorus and potassium percent (\%) as affected by sources and rates of nitrogen fertilizer produced from first and second cuttings as combined over both seasons.

\begin{tabular}{|c|c|c|c|c|c|c|c|c|c|c|c|c|}
\hline \multirow{2}{*}{ Cuttings } & \multicolumn{12}{|c|}{ Phosphorus (\%) } \\
\hline & \multicolumn{3}{|c|}{$50 \mathrm{~kg} \mathrm{~N} / \mathrm{fed}$} & \multicolumn{3}{|c|}{$75 \mathrm{~kg} \mathrm{N/fed}$} & \multicolumn{3}{|c|}{$100 \mathrm{~kg} \mathrm{~N} / \mathrm{fed}$} & \multicolumn{3}{|c|}{$125 \mathrm{~kg} \mathrm{~N} / \mathrm{fed}$} \\
\hline \multicolumn{13}{|c|}{ Ammonium nitrate " $\mathrm{NH}_{4} \mathrm{NO}_{3}$ " } \\
\hline First cutting & $0.238^{\text {an }}$ & \pm & 0.008 & $0.248^{b}$ & \pm & 0.004 & $0.280^{\mathrm{b}}$ & \pm & 0.003 & 0.279 & \pm & 0.007 \\
\hline Second cutting & $0.211^{\mathrm{b}}$ & \pm & 0.008 & $0.238^{b}$ & \pm & 0.003 & $0.270^{\circ}$ & \pm & 0.003 & 0.264 & \pm & 0.006 \\
\hline \multicolumn{13}{|c|}{ Ammonium sulphate " $\left(\mathrm{NH}_{4}\right)_{2} \mathrm{SO}_{4} "$} \\
\hline First cutting & $0.247^{\mathrm{a}}$ & \pm & 0.007 & $0.265^{\mathrm{a}}$ & \pm & 0.005 & $0.292^{\mathrm{a}}$ & \pm & 0.002 & 0.294 & \pm & 0.005 \\
\hline Second cutting & $0.231^{\text {tat }}$ & \pm & 0.007 & $0.246^{\mathrm{b}}$ & \pm & 0.005 & $0.271^{\text {be }}$ & \pm & 0.004 & $0.274^{\mathrm{b}}$ & \pm & 0.004 \\
\hline LSD at $5 \%$ & \multicolumn{3}{|c|}{0.14} & \multicolumn{3}{|c|}{0.08} & \multicolumn{3}{|c|}{0.06} & \multicolumn{3}{|c|}{0.10} \\
\hline \multicolumn{13}{|c|}{$\begin{array}{c}\text { Potassium (\%) } \\
\text { Ammonium nitrate " } \mathrm{NH}_{4} \mathrm{NO}_{3} "\end{array}$} \\
\hline First cutting & $2.410^{\mathrm{at} \mathrm{t}}$ & \pm & 0.060 & $2.686^{b}$ & \pm & 0.020 & $2.963^{\mathrm{a}}$ & \pm & 0.025 & 3.266 & \pm & 0.060 \\
\hline Second cutting & $2.296^{6}$ & \pm & 0.030 & $2.610^{\mathrm{b}}$ & \pm & 0.010 & $2.826^{\mathrm{a}}$ & \pm & 0.040 & 2.906 & \pm & 0.030 \\
\hline \multicolumn{13}{|c|}{ Ammonium sulphate " $\left(\mathrm{NH}_{4}\right)_{2} \mathrm{SO}_{4} "$} \\
\hline First cutting & $2.440^{3}$ & \pm & 0.060 & $2.856^{\mathrm{a}}$ & \pm & 0.061 & $2.990^{\mathrm{a}}$ & \pm & 0.572 & 3.343 & \pm & 0.025 \\
\hline Second cutting & $2.306^{\mathrm{at}}$ & & & $2.650^{\mathrm{b}}$ & & 0.036 & $2.850^{\mathrm{a}}$ & \pm & 0.045 & 2.956 & & 0.020 \\
\hline LSD at $5 \%$ & \multicolumn{3}{|c|}{$102>$} & \multicolumn{3}{|c|}{0.070} & \multicolumn{3}{|c|}{0.542} & \multicolumn{3}{|c|}{1.369} \\
\hline
\end{tabular}

The superscript letters indicated statistically significant differences, with $\mathrm{P}<0.05$.
Fertilizing sudangrass plants with $50 \mathrm{~kg} \mathrm{~N} / \mathrm{fed}$ as ammonium nitrate resulted in the lowest value of $\mathrm{P} \%$ and $\mathrm{K} \%$ in both cuttings of sudangrass. While higher values of $\mathrm{P} \%$ and $\mathrm{K} \%$ in the plant with $125 \mathrm{~kg} \mathrm{~N} / \mathrm{fed}$ as ammonium sulphate in the first and second cuttings. were obtained from fertilizing sudangrass plant
Moreover the data show also that phosphoru percent in sudangrass plants fertilized by "(NH4) (O) NO3", increasing fertilizer rates from 50 to 75 and $100 \mathrm{~kg} \mathrm{~N} / \mathrm{fed}$, showed that $\mathrm{p} \%$ and $\mathrm{K} \%$ in sudangrass plants were significantly increa in the first and the second cuttings in both seasons. 
But, increasing its rate from 100 to $125 \mathrm{kgN} / \mathrm{fed}$ caused remarkable decrease in $\mathrm{P} \%$ in sudangass plants for the first and the second cutting combined over both seasons. While, in the case of using "(NH4)2 SO4",data show that P \% and $\mathrm{K} \%$ in the plants were significantly increased as its rate increased from 50 to 75,100 and 125 $\mathrm{kg} \mathrm{N} /$ fed in the first and the second cuttings over both seasons. These results are in line with those obtained by Anfinruda et al.(2013) who reported that there was a significant response in $\mathrm{P} \%$ with increasing nitrogen rates.

4- Nitrite (NO2\%) and nitrate (NO3\%)

Averages of nitrite (NO2) and nitrate (NO3) in sudangrass plants as affected by various nitrogen ferl the socond cuttings as combined ove both seasons are shown in Table 5 .

$\mathrm{NO} 2$ and $\mathrm{NO} 3$ in sudangrass plants produced from the first cutting were significantly highe than those in the plants resulted from the second cutting . The obtained data showed also that $\mathrm{NO} 2$ in sudangrass plants fertilize by "NH4 NO3" was higher than those fertilized by "(NH4)2 SO4" in the first and the second cuttings over both seasons.

TABLE 5. Nitrite $\left(\mathrm{NO}_{2} \mathrm{ppm}\right)$ and nitrate $\left(\mathrm{NO}_{3} \mathrm{ppm}\right)$ contents as affected by sources and rates of nitrogen fertilizer produced from first and second cuttings as combined over both seasons.

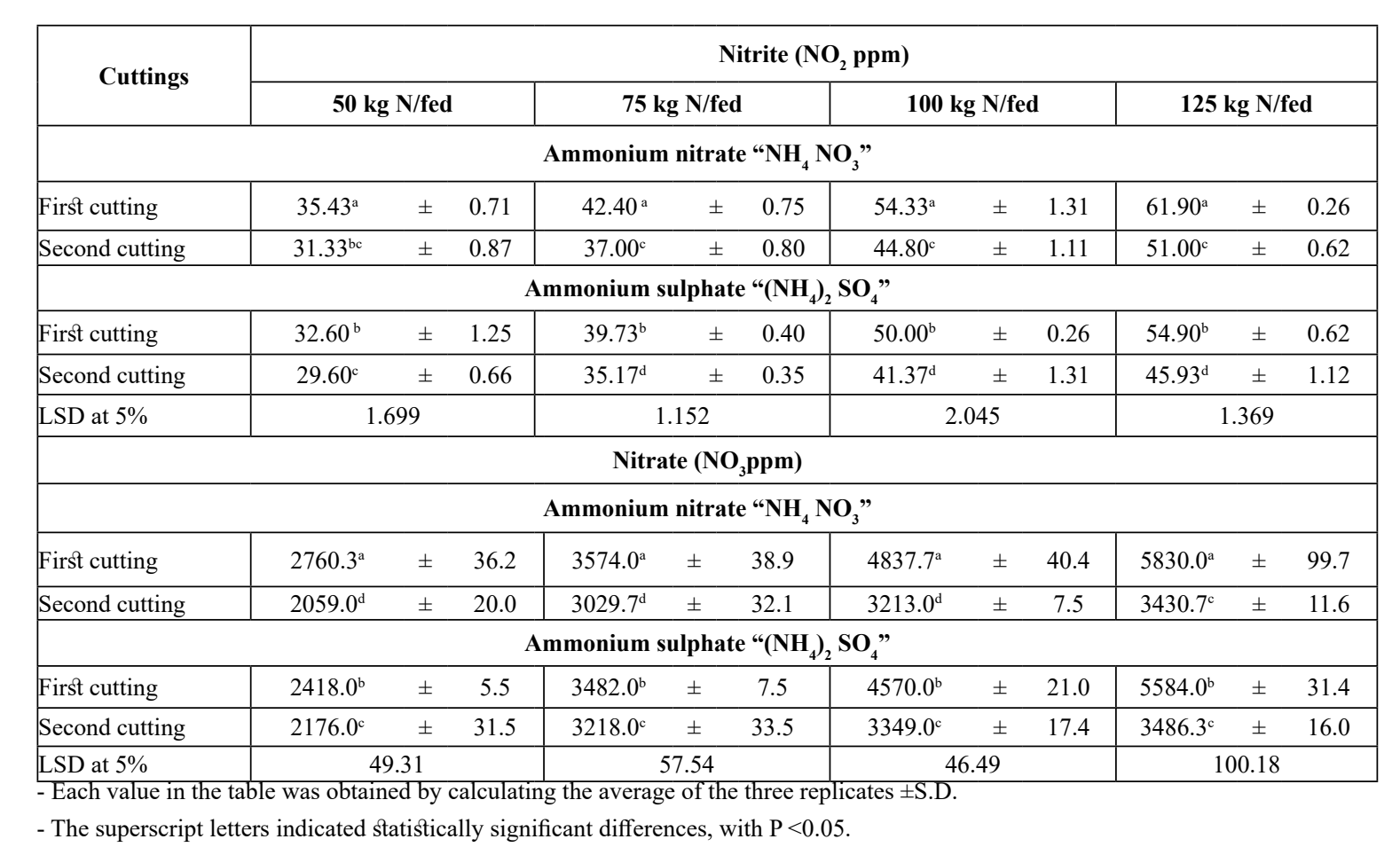

- The superscript letters indicated statistically significant differences, with $\mathrm{P}<0.05$.

Egypt. J. Soil Sci. 57 No.1, (2017)
Mineral fertilizing sudangrass plants at $50 \mathrm{~kg}$ $\mathrm{N} / \mathrm{fed}$ as ammonium sulphate (in the first cutting) By in the lowest values of $\mathrm{NO} 3$ in the plants. to 75,100 and $125 \mathrm{~kg} \mathrm{~N} / \mathrm{fed}, \mathrm{NO} 2$ and NO3i sudangrass plants were significantly increased in the first and the second cuttings as combined over both seasons. The increments in NO3 in sudangras plants as a result of increasing nitrogen fertilize tates up to $125 \mathrm{~kg} \mathrm{~N} /$ fed may be attributed to the sane reasons that mentioned in nitrogen percent and similar discussion could be cited. In this manner, Cupina et al. (2011) reported that nitrogen atres significantly affect NO3-N content.In both cithins of sudangrass, maximum value of $\mathrm{NO3}$ in the plants was produced from fertilizing with 125 $\mathrm{kg} \mathrm{N} /$ fed as ammonium nitrate (in the first cutting)
and as ammonium sulphate (in the second cutting).

According to Ensley and Barnhart (2012). It can be recommended that mineral fertilization of sudangrass with $75-100 \mathrm{kgN} / \mathrm{fed}$ in order get suitable feed quality respecting $\mathrm{NO}$ restricted to $25 \%$ of the total ration DM. and as ammonium nitrate (in the second cutting)

\begin{tabular}{|c|c|}
\hline $\mathrm{NO}_{3}-\mathrm{N}(\mathrm{ppm})^{*}$ & Response \\
\hline$<1000$ & $\begin{array}{l}\text { Safe to feed: Use caution when feeding pregnant or young animals, } \\
\text { and prevent over-consumption. }\end{array}$ \\
\hline $1000-2000$ & $\begin{array}{l}\text { Generally safe when fed balanced rations. Best to limit to half of the } \\
\text { total dry ration for pregnant animals and also be sure water is low in } \\
\text { nitrate. }\end{array}$ \\
\hline $2000-4000$ & Feeds in this range should be restricted to $25 \%$ of the total ration DM. \\
\hline $4000-6000$ & $\begin{array}{l}\text { Moderately safe for most situations, limit use for stressed animals to } \\
50 \% \text { of the total ration. }\end{array}$ \\
\hline $6000-9000$ & $\begin{array}{l}\text { Potentially toxic to cattle depending on the situation; should not be the } \\
\text { only source of feed. }\end{array}$ \\
\hline$>9000$ & Danger, do not feed: Potential for toxicity high. \\
\hline
\end{tabular}

\section{Reference}

A.O.A.C. (2012) Official Methods of Analysis of AOAC International. $11^{\text {th }}$ ed. Gaithersburg, MD, USA Association of Analytical Communities.

Afzal, M. , Ahmad , A. and Ahmad, AU.H. (2012)Effect of nitrogen on growth and yield of sorghum forag (Sorghum bicolor (L.) Moenchcv.) under three cuttings system. CercetăriAgronomiceîn Moldova XLV 4, 57-64.

Ahmed, Amal G., Zaki, Nabila M. and Hassanein, M.S. (2007) Response of grain sorghum to different nitrogen sources. Res. J. of Agric. and Biol. Sci. $3(6), 1002-1008$

Al-Suhaibani, N.A. (2006) Effect of irrigation intervals and nitrogen fertilizer rates on fresh forage yield of sudangrass [Sorghum sudanense (Piper) Stapf.].Res. Bull., Food Sci. \& Agric. Res. Cente, King Saud Univ., 142, 1-14.

Anfinruda, R., Cihacekb , L., Johnsona, B.L., Jic ,Y. and Bertia, M.T. (2013) Sorghum and kenaf biomas yield and quality response to nitrogen fertilization in the Northern Great Plains of the USA. Industria Crops and Products, 50,159-165.

Beyaert, R.P. and Roy, R.C. (2005) Influence of nitrogen fertilization on multi-cut forage sorghumsudangrass yield and nitrogen use. Agron. J., 97, 1493-1501.

Ćupina, B., Manojlović M., Krstić1, D., Ĉabilovski, R. Mikić, A., Ignjatović-Cupina, A. and Erić, P. (2011) Effect of winter cover crops on the dynamics of sol mineral nitrogen and yield and quality of Sudan grass [Sorghum bicolor (L.) Moench]. Australian of Crop Sci, $\mathbf{5}(7), 839-845$

El-Nahrawy, M.A. (2011) Country pasture/forage resource profiles, Egypt. FAO, Publishing Policy an Support Branch, Office of Knowledge Exchange, Caracalla, 00153 Rome, Italy, p. 27.

Ensley, S. and Barnhart, S.K. (2012) Nitrate toxicity Iowa State Univ, Iowa Beef Center, Outreach, Ames, Iowa, File: Animal Science 11

Fageria, N.K. and Baligar ,V.C. (2005) Enhancing nitrogen use eficiency in crop plant. Adv. Agron 88,97-185.

Gee,G.W. and Bauder, J.W. (1986)Particle-size analysis in :Klute, A. (Ed.), Methods of Soil Analysis, Part Mineralogical: Methods. Soil Sci Soc. Amer., Madison, WI, pp.383 - 411.

Gomez, K.N. and Gomez, A.A. (1984) Statistical procedures for Agricultural Research. John Wiley and Sons, New York, 2nd ed., 68 p.

Klute, A. (1986) Methods of Soil Analysis. Part I. Physical and Mineralogical Methods. Soil Sci Soc. Madison, Wisconsin, U.S.A.

Lawlor, D.W. (2002)Carbon and nitrogen assimilationin relation to yield: mechanisms are the key to understanding production systems. $J$. Exp. Botany. 53, 773-787.

Egypt. J. Soil Sci. 57 No. 1, (2017) 
Mahmoud, Safaa, A., Abd-Elfattah, M.S , Khaled, S.M and Siam, Hanan.S. (2011) Effect of cobalt, and nitrogen forms on nitrate accumulation in Jew's mallow plant as affected by a nitrification inhibitor (N-serve). J. of American Sci., 7(4),336-348.

O'Dell, J.W. (1993) Determination of total kjeldahl nitrogen by semi-automated colorimetry,Method 351.2. Environmental Monitoring Systems Laboratory Office of Research and Development U.S. Environmental Protection Agency Cincinnati, Ohio 45268, Revision 2.0.

Page, A. L. ,Miller, R. H. and Keeney, D.R. (1982) Methods of Soil Analysis, Part 2, 2, nd., Agronomy monograph No 9. ASA, SSSA Madison. 1159P.

Pierzynski, G.M. (2000) Methods of phosphorus analysis for soils, sediments, residuals, and waters. Southern Cooperative Series Bulletin No. 396, June, 2000.
Rahman, M.M., Yamamoto, M., Niimi, M. and Kawamura ,O. (2008) Effect of nitrogen fertilization on oxalate content in rhodesgrass, guineagrass and sudangrass. Asian-Aust. J. Anim. Sci., 21(2), 214-219.

Roozeboom, K. (2011) Nitrate Toxicity. Kansas State University Agricultural Experiment Station and Cooperative Extension Service.

Sparks, D. L. (1996) Soil Science Society of America; and American Society of Agronomy.Methods of Soil Analysis.Part 3, Chemical Methods. Soil Science Society of America book series, No.5,Madison.

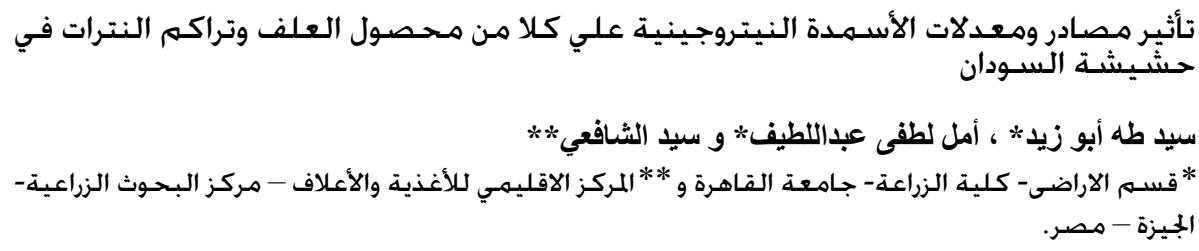

أجريت تجربة حقلية في محطة تجارب مركز البحوث الزر اعية بالجيزة خلال موسم الصيف لعامي 2012 و 2013 لدراسة

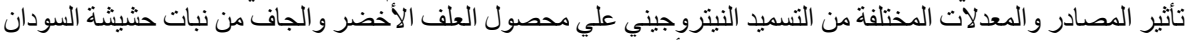

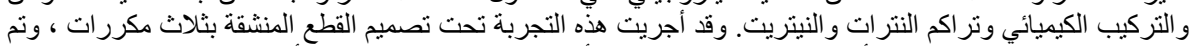

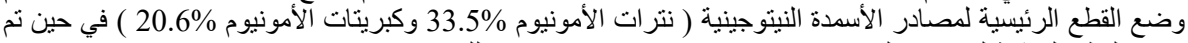

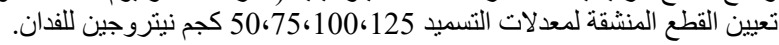

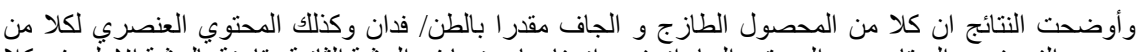

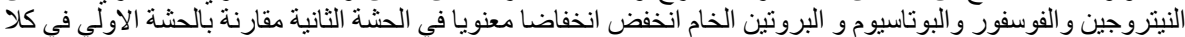

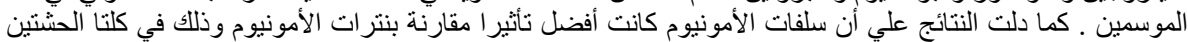

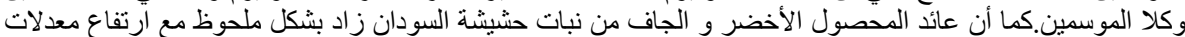

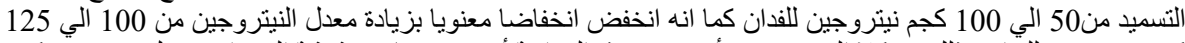

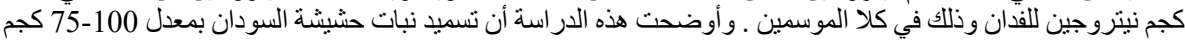
نيتروجين للفدان يعطي عائد من العلف مناسب وفي نفس الوقت هنت يحد من تر اكم النترات في النبات الكلمات الدالة : مصادر النيتروجين -تر اكم النترات - حشيشة السودان. 